\title{
Evaluasi Proyek Pembangunan Gedung Stroke Center (Paviliun Flamboyan) Menggunakan Metode Critical Path Method (CPM) Dan Crashing
}

\section{Evaluation of building construction Stroke Center (Paviliun Flamboyan) using the Critical Path Method (CPM) And Crashing Method}

\author{
Nihayatus Sa'adah ${ }^{1}$, Evany iqrammah $^{2}$, Tri Rijanto ${ }^{3}$ \\ ${ }^{1}$ Program Studi Teknik Sipil, Fakultas Teknik, Universitas Hasyim Asy’ari Tebuireng, Jombang, 61411, Indonesia. \\ Email : nihaya.as98@gmail.com \\ ${ }^{2}$ Program Studi Teknik Sipil, Fakultas Teknik, Universitas Hasyim Asy’ari Tebuireng, Jombang, 61411, Indonesia. \\ Email : vany010810.unhasy@gmail.com \\ ${ }^{3}$ Prgram Studi Teknik Sipil, Fakultas Teknik, Universitas Negeri Surabaya, Jln. Ketintang Surabaya, 60231, Indonesia. \\ Email : tririjanto@unesa.ac.id
}

\begin{abstract}
Abstrak
Kegiatan pembangunan proyek konstruksi sering terjadi keterlambatan. Pelaksanaan proyek konstruksi dibatasi oleh waktu dengan rencana biaya yang sudah ditentukan dalam perencanaan. Pengendalian yang tepat dapat mengurangi risiko terjadinya keterlambatan serta pembengkakan biaya. Salah satu proyek yang mengalami keterlambatan adalah pembangunan Gedung Stroke Center (Paviliun Flamboyan) RSUD Jombang. Faktor yang menjadi penyebab yaitu: (1) kurangnya kesiapan alat yang digunakan untuk mengakses ke tempat pembangunan, (2) posisi struktur tidak sesuai dengan perencanaan sehingga terjadi pembongkaran dan pengecoran ulang, (3) jalur mobilitas traffic alat berat yang sulit untuk mengakses ke tempat pembangunan sehingga berdampak terhadap pelaksanaan. Tujuan penelitian ini adalah (1) memperoleh informasi waktu pekerjaan pelaksanaan (2) mengetahui perbandingan biaya dan waktu adanya percepatan waktu pelaksanaan proyek. Metode yang dipakai adalah metode CPM (Critical Path Method) yang digunakan untuk menganalisis lintasan kritis yang fokus pada pekerjaan struktur beton dan menggunakan metode Crashing untuk mengetahui perbandingan biaya dan waktu akibat adanya percepatan (crashing). Hasil analisa pada penelitian ini diperoleh durasi pelaksanaan pekerjaan bangunan proyek secara normal. Dari analisa dengan alternatif penambahan tenaga kerja dan jam kerja (lembur) yaitu lebih hemat menggunakan alternatif jam kerja lembur dengan perbandingan sebesar $0.010 \%$.
\end{abstract}

Kata Kunci: Critical path method (CPM);, percepatan; waktu; biaya

\begin{abstract}
Construction project development activities often occur delays. The implementation of construction projects is limited by time with a cost plan that has been determined in the planning. Proper control reduces the risk of delays and cost overruns. One of the projects experiencing delays in development Gedung Stroke Center Paviliun Flamboyan RSUD Jombang. The factors that cause it are: (1) the lack of readiness of the tools used to access the construction site, (2) the position of the structure is not in accordance with the planning so that demolition and re-casting occur, (3) heavy equipment mobility traffic that is difficult to access to the construction site so that it has an impact on the implementation. The purpose of this study is (1) to obtain information on the time of execution of work (2) to determine the cost and time comparison of the acceleration of project implementation time. The method used is the CPM (Critical Path Method) method which is used to analyze the critical path that focuses on concrete structural work and uses the Crashing method to determine the comparison of costs and time due to acceleration (crashing). The results of the analysis in this study obtained the duration of the implementation of project building work normally. From the analysis with the alternative addition of manpower and working hours (overtime), it is more efficient to use alternative hours of overtime with a ratio of $0.010 \%$.
\end{abstract}

Keywords: Critical path method (CPM), crashing, time, cost 


\section{PENDAHULUAN}

Pembangunan proyek konstruksi di Indonesia menjadi tantangan tersendiri bagi dunia jasa konstruksi. Perusahaan dalam mengelola suatu proyek harus profesional, karena hal itu selalu dituntut untuk mendapatkan hasil yang baik, biaya yang bersaing dan mengerjakan sesuai prosedur waktu yang telah ditetapkan dalam perjanjian. Pada proyek penelitian ini terdapat kendala saat pembangunan proyek, baik kendala yang memang sudah diperhitungkan maupun kendala yang di luar perhitungan perencanaan. Adapun kendala yang dialami pada pembangunan Gedung Stroke Center (Paviliun Flamboyan), kurangnya kesiapan alat mobabilitas traffic alat berat yang digunakan untuk mengakses ke tempat pembangunan, posisi struktur tidak sesuai dengan proyek perencanaan sehingga terjadi pembongkaran dan pengecoran ulang.

Penelitian ini menganalisis di bagian aspek pekerjaan struktur beton yang mengalami critical, kemudian pada pekerjaan pasangan yang berada di minggu ke-10 juga mengalami critical (lintasan kritis). Lintasan dengan total durasi pekerjaan paling panjang disebut sebagai lintasan kritis. Analisa yang digunakan network planning yaitu untuk menganalisis lintasan kritis mengetahui perbandingan biaya dan waktu akibat adanya percepatan (crashing). Penelitian ini bermanfaat meminimalisir keberhasilan pembangunan proyek dengan melakukan analisa percepatan penyelesaian proyek menggunakan metode CPM (Critical Path Method) dan menggunakan Crashing. Sehingga metode ini dapat mengefisienkan waktu serta menghemat biaya pengerjaan proyek konstruksi.

\section{Rumusan Masalah}

Adapun rumusan masalah pada penelitian ini sebagai berikut.

1. Bagaimana hasil analisis perhitungan evaluasi waktu pekerjaan pelaksanaan proyek Pembangunan Gedung Stroke Center (Paviliun Flamboyan) RSUD Jombang dengan metode CPM (Critical Path Method) dan Crashing?

2. Bagaimana hasil perhitungan biaya (cost) yang diperlukan dengan adanya percepatan waktu pada pelaksanaan Pembangunan Gedung Stroke Center (Paviliun Flamboyan) RSUD Jombang dengan metode CPM (Critical Path Method) dan Crashing?

\section{Tujuan Penelitian}

Tujuan penelitian yang akan dicapai di dalam penulisan artikel antara lain ialah sebagai berikut.

1. Memperoleh informasi evaluasi waktu pekerjaan pelaksanaan proyek Pembangunan Gedung Stroke Center (Paviliun Flamboyan) RSUD Jombang.

2. Mengetahui perbandingan biaya akibat adanya percepatan waktu pelaksanaan proyek Pembangunan Gedung Stroke Center (Paviliun Flamboyan) RSUD Jombang.

\section{TINJAUAN PUSTAKA}

\section{Metode Critical Path Method (CPM)}

Critical Path Method (CPM) di dasarkan pada aspek yang memakai kesetaraan antara durasi dan anggaran linear. Setiap aktivitas diselesaikan lebih awal dari durasi normal dengan cara melewati aktivitas untuk sejumlah anggaran tertentu. Oleh dari itu, apabila durasi penyelesaian proyek kurang memuaskan maka, kegiatan tertentu akan dilewati untuk bisa memutuskan proyek dalam durasi yang lebih pendek. CPM dapat memperkirakan durasi yang diperlukan dalam melakukan pelaksanaan kegiatan proyek dan dapat menetapkan prioritas kegiatan yang harus memperoleh pengawasan secara efisien sehingga kegiatan bisa terselesaikan sesuai dengan perencanaan. Metode ini disebut sebagai jalur kritis, dikarenakan pada metode ini akan membentuk sebuah jaringan lintasan kritis yang harus mendapat perhatian pengawasan secara khusus.

\section{Jaringan Kerja}

Perencanaan jaringan (Network planning) pada dasarnya dapat berupa hubungan yang saling mempengaruhi antara bagian pekerjaan pada diagram jaringan. Dapat dinyatakan bahwa bagian pekerjaan yang perlu didahulukan, sehingga dapat dipakai sebagai dasar dalam penyelesaian pekerjaan berikutnya serta dapat juga dilihat bahwa pekerjaan tidak dapat dimulai apabila kegiatan yang awal belum selesai. Simbol-simbol yang digambarkan dalam diagram jaringan kerja yaitu.

a) $\longrightarrow$ (anak panah/busur), mewakili suatu kegiatan yang diperlukan oleh proyek. Kegiatan di sini diartikan sebagai hal yang membutuhkan durasi tertentu dalam penggunaan berbagai sumber daya (sumber tenaga, peralatan, bahan, biaya). 
b) $\mathbf{O}$ (lingkaran kecil/simpul/node), mewakili suatu peristiwa. Kejadian ini didefinisikan sebagai awal pertemuan dari beberapa kegiatan. Sebuah kejadian mewakili beberapa batas durasi yang juga mewakili dalam penyelesaian beberapa kegiatan, oleh karena itu titik awal serta akhir suatu kegiatan ditentukan oleh dua peristiwa.

c) $-\leadsto$ (anak panah terputus-putus), menyatakan semua aktivitas dummy. Setiap panah memiliki peranan double dalam mewakili aktivitas dan membantu untuk menunjukkan hubungan utama antara berbagai aktivitas. Dummy ini bermanfaat sebagai pembatas awal aktivitas, panjang dan kemiringan dummy tidak memiliki arti sehingga tidak perlu di skala.

d) $\longrightarrow$ (anak panah tebal), adalah aktivitas pada jalur kritis.

\section{Lintasan Kritis}

Heizer dan Render (2005) menjelaskan bahwa dalam melakukan analisis jalur kritis, digunakan dua proses two-pass, terdiri atas forward pass dan backward pass. ES dan EF ditentukan selama forward pass, LS dan LF ditentukan selama backward pass. ES (earliest start) adalah waktu terdahulu suatu 24 kegiatan dapat dimulai, dengan asumsi semua pendahulu sudah selesai. EF (earliest finish) merupakan waktu terdahulu suatu kegiatan dapat selesai. LS (latest start) adalah waktu terakhir suatu kegiatan dapat dimulai sehingga tidak menunda waktu penyelesaian keseluruhan proyek. LF (latest finish) adalah waktu terakhir suatu kegiatan dapat selesai sehingga tidak menunda waktu penyelesaian keseluruhan proyek.

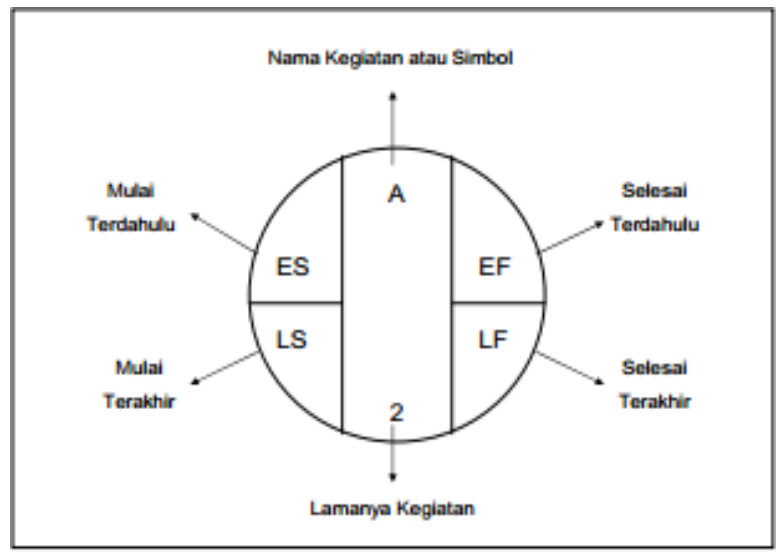

Gambar 1. Notasi yang Digunakan pada Node Kegiatan

\section{Metode Percepatan Crashing}

Crashing merupakan metode yang disengaja, sistematis, dan analitis dengan menguji semua aktivitas dalam proyek yang dipusatkan pada kegiatan yang berada di jalur kritis. Terminologi proses crashing adalah dengan mereduksi durasi suatu pekerjaan yang akan berpengaruh terhadap waktu penyelesaian proyek. Metode ini dapat berupa suatu proses dalam mengurangi durasi penyelesaian proyek yang diselesaikan secara sengaja. Metode Crashing berfungsi untuk mengoptimalkan durasi kerja tetapi dengan biaya yang efisien. Metode crashing dalam pelaksanaan proyek pasti akan mengalami kondisi time cost trade of dalam durasi pengerjaan dengan tambahan biaya yang efisien. Metode crashing dikonsentrasikan pada pengurangan durasi aktivitas terhadap jalur kritis. jalur kritis termasuk pengaruh besar pada keterlambatan proyek karena tidak ada kelonggaran durasi jalur kritis. terdapat beberapa metode yang digunakan dalam melakukan metode crashing yaitu.

\section{Penambahan Tenaga Kerja}

Produktivitas tenaga kerja merupakan besarnya kuantitas pekerjaan yang dapat diselesaikan oleh seorang tenaga kerja setiap harinya. John Soeprihanto menyatakan bahwa produktivitas dapat berupa perselisihan antara hasil yang diperoleh dengan kebutuhan sumber daya yang terpengaruh secara umum atau perselisihan total produksi (output) dengan sumber daya yang digunakan (input).

Produktivitas tenaga kerja $=\frac{1}{\text { koefisien tenaga kerja }}$

Terdapat persamaan yang menyatakan produktivitas tenaga kerja menurut Cornelia (2003), yaitu.

$$
\begin{aligned}
& \text { Produktivitas tenaga kerja }=\frac{V}{T x N} \\
& \begin{array}{ll}
\text { Dimana : } \\
\mathrm{V} \quad \text { = Kuantitas pekerjaan } \\
\mathrm{T} \quad \text { = Durasi pekerjaan } \\
\mathrm{n} & =\text { Jumlah tenaga kerja }
\end{array}
\end{aligned}
$$

Tenaga kerja adalah setiap orang yang mampu melakukan pekerjaan guna menghasilkan barang dan atau jasa baik untuk memenuhi kebutuhan sendiri maupun untuk masyarakat. Sedangkan ketenagakerjaan merupakan segala hal yang berhubungan dengan tenaga kerja pada saat sebelum kerja atau selama masa kerja. Jam kerja pada umumnya yaitu 7 jam setiap hari serta 40 jam per minggu selama 6 hari bekerja. Karyawan yang bekerja 5 hari di kurun waktu seminggu dikenai kewajiban 8 jam per hari serta 40 jam dalam waktu seminggu (UU No. 13 Tahun 2003 Tentang Ketenagakerjaan). 


\section{Penambahan Jam Kerja Lembur}

Pekerja yang dikerjakan saat di luar jam kerja yaitu dinamakan dengan pekerjaan jam kerja lembur. Perencanaan kerja yang diterapkan untuk mempersingkat pelaksanaan pekerjaan yaitu dengan menggunakan tambahan jam kerja sebagai berikut.

1. Durasi normal dalam jam kerja ialah 8 jam, apabila akan dilakukan jam kerja lembur yaitu setelah jam normal selesai.

2. Perhitungan upah jam lembur menurut Keputusan Menteri Tenaga Kerja Nomor KEP.102/MEN/VI/2004 Tentang Waktu Kerja Lembur dan Upah Kerja Lembur Pasal 11, yang sebelumnya sudah diatur pada pasal $3 \& 8$ diperhitungkan sebagai berikut.

a. Perhitungan upah lembur berdasarkan pada upah bulanan.

b. Cara menghitung upah lembur per jam adalah 1/173 kali upah sebulan. Rumus.

1) Upah jam lembur pertama $=1,5 \mathrm{x}$ 1/173 x upah sebulan

2) Upah jam lembur kedua dan seterusnya $=2 \times 1 / 173 \times$ upah sebulan

c. Waktu kerja lembur hanya dapat dilakukan paling banyak 3 (tiga) jam dalam 1 (satu) hari dan 14 (empat belas) jam dalam 1 (satu) minggu.

\section{METODE}

\section{Diagram Alir Penelitian}

Proyek pembangunan berlokasi di Jln. Wahid Hasyim No. 52, Kec. Jombang, Kab. Jombang, Jawa Timur 64212 yang dikerjakan oleh CV. Elemen Tiga Tiga. Objek penelitian adalah proyek pembangunan Gedung Stroke Center (Paviliun Flamboyan), berupa analisa untuk mengevaluasi waktu penjadwalan proyek yang diakibatkan oleh keterlambatan proyek. Metode penelitian ini bertujuan untuk mengetahui durasi dan anggaran biaya yang dibutuhkan dalam pelaksanaan konstruksi dengan menggunakan metode Critical Path Method (CPM) dan Crashing. Dalam menganalisis data yaitu dengan teknik metode analitis dan teknik metode deskriptif. Adapun tahapan penelitian dapat dilihat pada diagram di bawah ini.

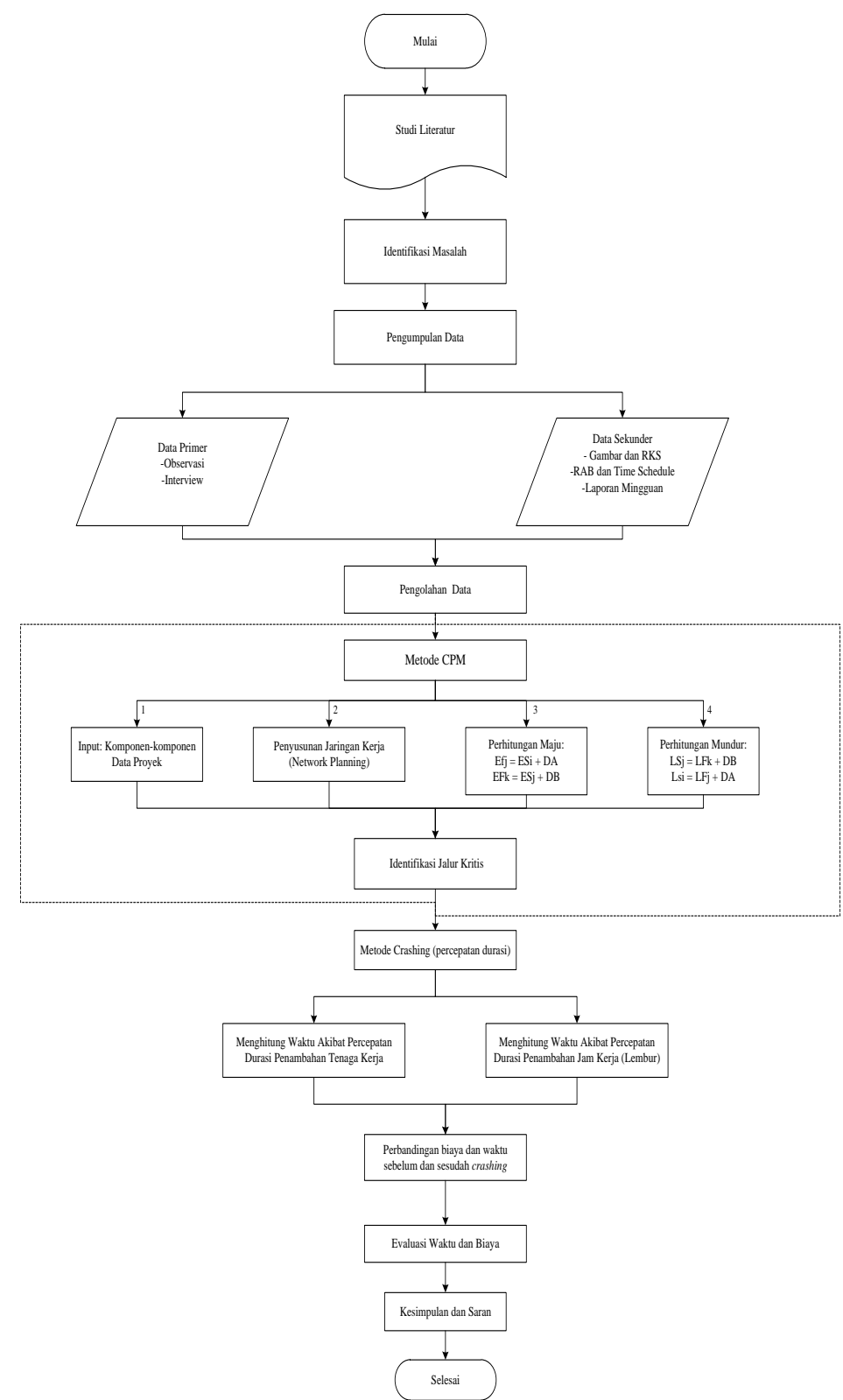

Gambar 2. Diagram Alur Penelitian (Sumber: Analisis Penelitian 2021)

Adapun penjelasan tahapan atau prosedur yang akan dilakukan terhadap penelitian ini yaitu.

1. Studi pustaka yaitu merupakan bahan referensi atau sumber informasi yang dijadikan sebagai acuan pada penelitian penulisan artikel.

2. Tahapan pengumpulan data di dalam penelitian ini yaitu berkaitan dengan data primer seperti interview kepada pihak yang bersangkutan dan data sekunder yaitu meliputi: Time Schedule, Shop Drawing, dan Laporan Mingguan proyek pembangunan Gedung Stroke Center (Paviliun Flamboyan).

3. Analisis Data

a. Tahapan awal pengolahan yaitu menggunakan metode CPM dengan memakai data yang telah diperoleh dari

Proteksi/Desember 2021 Volume 3 No. 2 
hasil studi pengumpulan data sebelumnya.

b. Tahapan analisis selanjutnya yaitu menggunakan metode Crashing dilakukan setelah lintasan kritis diketahui. Pada metode Crashing melakukan percepatan durasi proyek dengan penambahan jam kerja (lembur) dan penambahan tenaga kerja.

\section{HASIL DAN PEMBAHASAN}

\section{Tahapan Analisa Metode Critical Path Method (CPM)}

1. Penyusunan Work Breakdown Structure

Tahapan awal dalam pengolahan dan analisis data yaitu menyusun Work Breakdown Structure (WBS) yang digunakan untuk melakukan penguraian terhadap masing-masing pekerjaan dalam proyek supaya lebih jelas dan spesifik. Dengan WBS, pekerjaan dalam proyek maka akan terbagi menjadi sub pekerjaan atau aktivitas dimana disusun berdasarkan level.

Tabel 1. Ketergantungan Kegiatan Proyek Gedung Stroke Center (Paviliun)

No. Uraian Pekerjaan $\begin{gathered}\text { Kode } \\ \text { Kegiatan }\end{gathered}$ Predecessors $\begin{gathered}\text { Estimated } \\ \text { Time }\end{gathered}$

\begin{tabular}{|c|c|c|c|c|}
\hline & LANTAI 1 & & & \\
\hline 1 & Lantai kerja $5 \mathrm{~cm}$ & $\mathrm{~A}$ & - & 31 \\
\hline 2 & Strous $\varnothing 30 \mathrm{~cm}$ & $\mathrm{~B}$ & $\mathrm{~A}$ & 26 \\
\hline 3 & $\begin{array}{l}\text { Pondasi Plat beton } \\
\text { menerus 20/100 }\end{array}$ & $\mathrm{C}$ & A & 21 \\
\hline 4 & $\begin{array}{l}\text { Pondasi Plat } \\
140 \times 140 \times 50 \mathrm{~cm} \\
\mathrm{~K} 250\end{array}$ & $\mathrm{D}$ & $\mathrm{B}$ & 11 \\
\hline 5 & $\begin{array}{l}\text { Pondasi Plat } \\
50 \times 140 \times 50 \mathrm{~cm} \mathrm{~K} 250\end{array}$ & $\mathrm{E}$ & A & 21 \\
\hline 6 & Sloof 20/30 K250 & $\mathrm{F}$ & $\mathrm{D}, \mathrm{B}$ & 16 \\
\hline 7 & Kolom Beton 35/35 & $\mathrm{G}$ & $\mathrm{C}$ & 21 \\
\hline 8 & Kolom Beton 15/15 & $\mathrm{H}$ & $\mathrm{R}$ & 6 \\
\hline 9 & Balok 20/30 & I & $\mathrm{F}$ & 6 \\
\hline 10 & Balok 15/30 & $\mathrm{J}$ & $\mathrm{G}$ & 6 \\
\hline 11 & Balok 25/45 & $\mathrm{K}$ & I & 6 \\
\hline 12 & Plat deck $\mathrm{t}=12 \mathrm{~cm}$ & $\mathrm{~L}$ & $\mathrm{~J}$ & 6 \\
\hline 13 & Balok lantai 12/20 & M & $\mathrm{K}$ & 11 \\
\hline \multirow[t]{2}{*}{14} & Kanopi 5/50 & $\mathrm{N}$ & $\mathrm{P}$ & 6 \\
\hline & LANTAI 2 & & & \\
\hline 15 & Kolom Beton 35/35 & $\mathrm{O}$ & $\mathrm{Q}, \mathrm{M}$ & 6 \\
\hline 16 & Kolom Beton 15/15 & $\mathrm{P}$ & $\mathrm{E}$ & 11 \\
\hline 17 & Balok 20/30 & $\mathrm{Q}$ & $\mathrm{K}$ & 16 \\
\hline 18 & Balok 15/30 & $\mathrm{R}$ & $\mathrm{AB}$ & 16 \\
\hline 19 & Balok 25/45 & $\mathrm{S}$ & $\mathrm{P}$ & 16 \\
\hline 20 & Plat deck $\mathrm{t}=12 \mathrm{~cm}$ & $\mathrm{~T}$ & $\mathrm{~V}$ & 16 \\
\hline 21 & $\begin{array}{l}\text { Plat deck selasar } \mathrm{t}=8 \\
\mathrm{~cm}\end{array}$ & $\mathrm{U}$ & $\mathrm{T}, \mathrm{O}$ & 6 \\
\hline 22 & Balok lantai 12/20 & $\mathrm{V}$ & $\mathrm{W}, \mathrm{X}$ & 6 \\
\hline 23 & Kanopi 5/50 & $\mathrm{W}$ & $\mathrm{L}$ & 21 \\
\hline \multirow[t]{2}{*}{24} & Pas. WF 250.125.6.9 & $\mathrm{X}$ & $\mathrm{L}$ & 21 \\
\hline & LANTAI 3 & & & \\
\hline 25 & Kolom Beton 35/35 & $\mathrm{Y}$ & $\mathrm{U}, \mathrm{O}$ & 11 \\
\hline 26 & Kolom Beton 15/15 & $\mathrm{Z}$ & $\mathrm{N}$ & 11 \\
\hline
\end{tabular}

\begin{tabular}{llccc}
\hline No. & Uraian Pekerjaan & $\begin{array}{c}\text { Kode } \\
\text { Kegiatan }\end{array}$ & Predecessors & $\begin{array}{c}\text { Estimated } \\
\text { Time }\end{array}$ \\
\hline 27 & Balok $20 / 30$ & AA & AD & 11 \\
\hline 28 & Balok $15 / 30$ & AB & AC & 11 \\
\hline 29 & Balok 25/45 & AC & Z,AA & 11 \\
\hline 30 & Balok 15/25 & AD & S & 6 \\
\hline 31 & Konsol 20/30 & AE & T & 11 \\
\hline 32 & Plat deck t=12 cm & AF & Y,H & 11 \\
\hline 33 & Balok latai $12 / 20$ & AG & AF & 21 \\
\hline 34 & Kanopi 5/50 & AH & AG,AE & 21 \\
\hline
\end{tabular}

(Sumber: Hasil Analisis 2021)

\section{Mengembangkan Hubungan Antara Aktivitas}

Tahapan dalam penyusunan suatu kegiatan untuk menghasilkan mata rantai yang sesuai dengan perkiraan logika ketergantungan network planning. Hasil dari mata rantai penyusunan kegiatan yang sesuai logika merupakan suatu dasar dalam pembuatan network planning, sehingga dapat diketahui urutan awal sampai akhir penyelesaian proyek. Terdapat beberapa kemungkinan yang terjadi dalam network planning dari hubungan antar kegiatan yang disusun menjadi mata rantai.

\section{Pembuatan Network Diagram}

Tahapan ini dilakukan pembuatan network diagram atau jaringan kerja pada Proyek Pembangunan Gedung Stroke Center (Paviliun Flamboyan). Network diagram dibentuk berdasarkan logika ketergantungan suatu aktivitas dengan aktivitas lain dalam menyelesaikan proyek secara keseluruhan. Penyusunan network diagram pada proyek dengan menggunakan pendekatan AON (Activity on Node). Berikut Gambar network diagram atau jaringan kerja dari Proyek Pembangunan Gedung Stroke Center (Paviliun Flamboyan) dengan menggunakan software POM For Windows V4. 


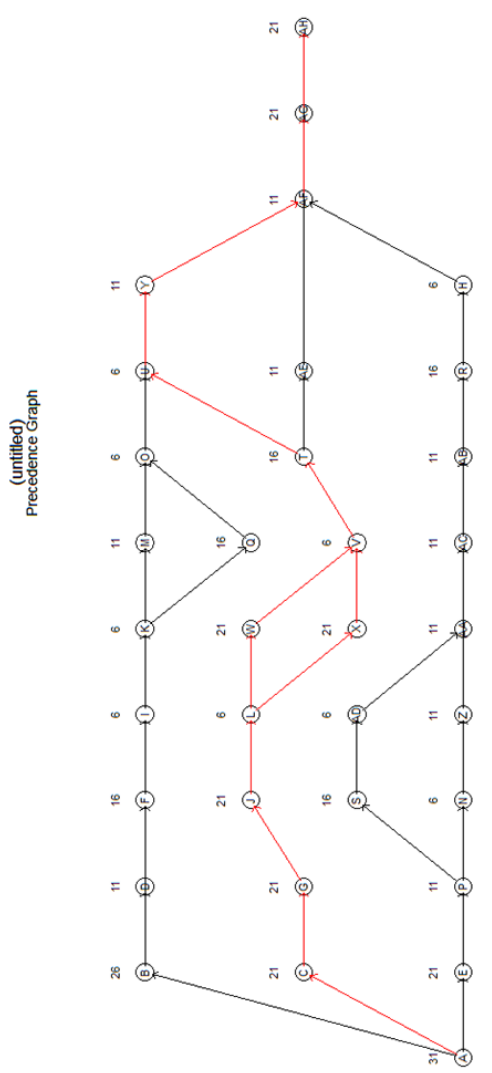

Gambar 3. Network Diagram Proyek Pembangunan Gedung Stroke Center (Paviliun Flamboyan)

(Sumber: Hasil Analisis 2021)

\section{Identifikasi Jalur Kritis}

Penetapan lintasan kritis dalam analisa ini menggunakan POM For Windows V4 yang ditampilkan dalam diagram. Setelah network diagram dibuat tahapan selanjutnya yaitu mengidentifikasi jalur kritis dengan menggunakan Critical Path Method (CPM) pada Proyek Pembangunan Gedung Stroke Center (Paviliun Flamboyan). Dengan CPM, maka dapat mengetahui lintasan kritis yang memiliki rangkaian aktivitas dengan jumlah durasi terpanjang. Jalur kritis dapat ditentukan terlebih dahulu dengan melakukan 2 cara perhitungan yaitu forward pass dan backward pass untuk menentukan Earliest Start (ES), Earliest Finish (EF), Latest Start (LS), dan Latest Finish (LF).

Tabel 2. Hasil Perhitungan CPM Dan Crashing

\begin{tabular}{ccccccccc}
\hline No. Activity & $\begin{array}{c}\text { Estimated } \\
\text { Time }\end{array}$ & ES & EF & LS & LF & Slack & $\begin{array}{c}\text { On } \\
\text { Critical } \\
\text { Path }\end{array}$ \\
\hline 1 & A & 31 & 0 & 31 & 0 & 31 & 0 & Kritis \\
\hline 2 & B & 26 & 31 & 57 & 67 & 93 & 36 & $\begin{array}{c}\text { Non } \\
\text { kritis }\end{array}$ \\
\hline 3 & C & 21 & 31 & 52 & 31 & 52 & 0 & Kritis \\
\hline 4 & D & 11 & 26 & 37 & 93 & 104 & 67 & $\begin{array}{c}\text { Non } \\
\text { kritis }\end{array}$ \\
\hline 5 & E & 21 & 31 & 52 & 67 & 88 & 36 & $\begin{array}{c}\text { Non } \\
\text { kritis }\end{array}$ \\
\hline 6 & F & 16 & 57 & 73 & 104 & 120 & 47 & $\begin{array}{c}\text { Non } \\
\text { kritis }\end{array}$ \\
\hline 7 & G & 21 & 52 & 73 & 52 & 73 & 0 & Kritis \\
\hline 8 & H & 6 & 134 & 140 & 154 & 160 & 20 & $\begin{array}{c}\text { Non } \\
\text { kritis }\end{array}$ \\
\hline & & & & & & & &
\end{tabular}

\begin{tabular}{|c|c|c|c|c|c|c|c|c|}
\hline No. & Activity & $\begin{array}{c}\text { Estimated } \\
\text { Time }\end{array}$ & ES & $\mathbf{E F}$ & LS & $\mathbf{L F}$ & Slack & $\begin{array}{c}\text { On } \\
\text { Critical } \\
\text { Path }\end{array}$ \\
\hline 9 & I & 6 & 73 & 79 & 120 & 126 & 47 & $\begin{array}{c}\text { Non } \\
\text { kritis }\end{array}$ \\
\hline 10 & $\mathrm{~J}$ & 21 & 73 & 94 & 73 & 94 & 0 & Kritis \\
\hline 11 & $\mathrm{~K}$ & 6 & 79 & 85 & 126 & 132 & 47 & $\begin{array}{c}\text { Non } \\
\text { kritis }\end{array}$ \\
\hline 12 & $\mathrm{~L}$ & 6 & 94 & 100 & 94 & 100 & 0 & Kritis \\
\hline 13 & M & 11 & 85 & 96 & 132 & 143 & 47 & $\begin{array}{l}\text { Non } \\
\text { kritis }\end{array}$ \\
\hline 14 & $\mathrm{~N}$ & 6 & 63 & 69 & 99 & 105 & 36 & $\begin{array}{l}\text { Non } \\
\text { kritis }\end{array}$ \\
\hline 15 & $\mathrm{O}$ & 6 & 101 & 107 & 143 & 149 & 42 & $\begin{array}{c}\text { Non } \\
\text { kritis }\end{array}$ \\
\hline 16 & $\mathrm{P}$ & 11 & 52 & 63 & 88 & 99 & 36 & $\begin{array}{c}\text { Non } \\
\text { kritis }\end{array}$ \\
\hline 17 & Q & 16 & 85 & 101 & 127 & 143 & 42 & $\begin{array}{c}\text { Non } \\
\text { kritis }\end{array}$ \\
\hline 18 & $\mathrm{R}$ & 16 & 118 & 134 & 138 & 154 & 20 & $\begin{array}{c}\text { Non } \\
\text { kritis }\end{array}$ \\
\hline 19 & $S$ & 16 & 63 & 79 & 83 & 99 & 20 & $\begin{array}{c}\text { Non } \\
\text { kritis }\end{array}$ \\
\hline 20 & $\mathrm{~T}$ & 16 & 127 & 143 & 127 & 143 & 0 & Kritis \\
\hline 21 & $\mathrm{U}$ & 6 & 143 & 149 & 143 & 149 & 0 & Kritis \\
\hline 22 & $\mathrm{~V}$ & 6 & 121 & 127 & 121 & 127 & 0 & Kritis \\
\hline 23 & $\mathrm{~W}$ & 21 & 100 & 121 & 100 & 121 & 0 & Kritis \\
\hline 24 & $\mathrm{X}$ & 21 & 100 & 121 & 100 & 121 & 0 & Kritis \\
\hline 25 & $\mathrm{Y}$ & 11 & 149 & 160 & 149 & 160 & 0 & Kritis \\
\hline 26 & $\mathrm{Z}$ & 11 & 69 & 80 & 105 & 116 & 36 & $\begin{array}{c}\text { Non } \\
\text { kritis }\end{array}$ \\
\hline 27 & AA & 11 & 85 & 96 & 105 & 116 & 20 & $\begin{array}{c}\text { Non } \\
\text { kritis }\end{array}$ \\
\hline 28 & $\mathrm{AB}$ & 11 & 107 & 118 & 127 & 138 & 20 & $\begin{array}{l}\text { Non } \\
\text { kritis }\end{array}$ \\
\hline 29 & $\mathrm{AC}$ & 11 & 96 & 107 & 116 & 127 & 20 & $\begin{array}{c}\text { Non } \\
\text { kritis }\end{array}$ \\
\hline 30 & $\mathrm{AD}$ & 6 & 79 & 85 & 99 & 105 & 20 & $\begin{array}{c}\text { Non } \\
\text { kritis }\end{array}$ \\
\hline 31 & $\mathrm{AE}$ & 11 & 143 & 154 & 181 & 192 & 38 & $\begin{array}{c}\text { Non } \\
\text { kritis }\end{array}$ \\
\hline 32 & $\mathrm{AF}$ & 11 & 160 & 171 & 160 & 171 & 0 & Kritis \\
\hline 33 & AG & 21 & 171 & 192 & 171 & 192 & 0 & Kritis \\
\hline 34 & $\mathrm{AH}$ & 21 & 192 & 213 & 192 & 213 & 0 & Kritis \\
\hline
\end{tabular}

(Sumber: Hasil Analisis 2021)

\section{Tahapan Analisa Metode Crashing}

\section{Analisa Penambahan Tenaga Kerja}

Analisa pada penambahan tenaga yaitu menggunakan penambahan $15 \%$ dari jumalah pekerja.

Tabel 3. Hasil Perhitungan Penambahan Tenaga Kerja

\begin{tabular}{clcc}
\hline No & Uraian Pekerjaan & $\begin{array}{c}\text { Normal } \\
\text { Tenaga } \\
\text { Kerja }\end{array}$ & $\begin{array}{c}\text { Penambahan } \\
\text { 15\% Tenaga } \\
\text { Kerja }\end{array}$ \\
\hline 1 & Lantai Kerja $5 \mathrm{~cm}$ & 13 & 16 \\
\hline 2 & $\begin{array}{l}\text { Fondasi Plat Beton } \\
\text { Menerus 20/100 }\end{array}$ & 19 & 23 \\
\hline 3 & Kolom Beton 35/35 & 7 & 10 \\
\hline 4 & Balok 15/30 & 1 & 2 \\
\hline 5 & Plat Deck t=12 cm & 14 & 16 \\
\hline 6 & Plat Deck t=12 cm & 14 & 16 \\
\hline 7 & Plat Deck Selasar t=8 & 1 & 2 \\
\hline 8 & Balok Lantai $12 / 20$ & 1 & 2 \\
\hline 9 & Kanopi $5 / 50$ & 1 & 6 \\
\hline 10 & Pas WF 250.125 .6 .9 & 4 & 2 \\
\hline 11 & Plat Deck t=12 cm & 12 & 2 \\
\hline 12 & Balok Lantai $12 / 20$ & 1 & 1 \\
\hline 13 & Kanopi $5 / 50$ & 1 & 2 \\
\hline
\end{tabular}

(Sumber: Hasil Analisis 2021)

Proteksi/Desember 2021 Volume 3 No. 2 
Tabel 4. Perhitungan Upah Dan Durasi Dengan Alternatif Penambahan Tenaga Kerja

\begin{tabular}{|c|c|c|c|c|}
\hline No. & Uraian Pekerjaan & $\begin{array}{c}\text { Durasi } \\
\text { Awal }\end{array}$ & $\begin{array}{c}\text { Durasi } \\
\text { Setelah } \\
\text { Crash } \\
\text { Tenaga } \\
\text { Kerja } \\
\end{array}$ & $\begin{array}{l}\text { Upah Setelah } \\
\text { Crash dengan } \\
\text { penambahan } \\
\text { Tenaga Kerja }\end{array}$ \\
\hline 1 & Lantai Kerja $5 \mathrm{~cm}$ & 31 & 25 & $601,500.00$ \\
\hline 2 & $\begin{array}{l}\text { Fondasi Plat Beton } \\
\text { Menerus 20/100 }\end{array}$ & 21 & 18 & $2,462,000.00$ \\
\hline 3 & Kolom Beton 35/35 & 21 & 18 & $1,639,000.00$ \\
\hline 4 & Balok 15/30 & 6 & 5 & $1,081,500.00$ \\
\hline 5 & Plat Deck $\mathrm{t}=12 \mathrm{~cm}$ & 6 & 5 & $1,729,000.00$ \\
\hline 6 & Plat Deck $t=12 \mathrm{~cm}$ & 16 & 14 & $2,074,500.00$ \\
\hline 7 & $\begin{array}{l}\text { Plat Deck Selasar } \mathrm{t}=8 \\
\mathrm{~cm}\end{array}$ & 6 & 5 & $886,500.00$ \\
\hline 8 & Balok Lantai 12/20 & 6 & 5 & $1,081,500.00$ \\
\hline 9 & Kanopi 5/50 & 21 & 18 & $1,081,500.00$ \\
\hline 10 & Pas WF 250.125.6.9 & 21 & 14 & $526,000.00$ \\
\hline 11 & Plat Deck t=12 cm & 11 & 9 & $1,639,000.00$ \\
\hline 12 & Balok Lantai 12/20 & 21 & 20 & $1,081,500.00$ \\
\hline 13 & Kanopi 5/50 & 21 & 20 & $1,081,500.00$ \\
\hline & Total & \multicolumn{3}{|c|}{$16,965,000.00$} \\
\hline
\end{tabular}

(Sumber: Hasil Analisis 2021)

\section{Analisa Penambahan Jam Kerja (Lembur)}

Tahapan analisa menambahakn jam kerja adalah suatu alternatif untuk mempersingkat waktu pelaksanaan proyek apabila ketersediaan pekerja tidak ada. Pada analisa ini menggunakan alternatif penambahan 2 jam kerja lembur dari jam kerja normal, dengan diketahui perhitungan sebelumnya produktivitas pekerjaan normal. Indeks produktivitas menurut Soeharto dapat dihitung nilai penurunan produktivitas per jam dengan rumus. Penurunan produktivitas jam ke $1=\frac{1}{1,1}=0,909$ Penurunan produktivitas jam ke $2=\frac{1}{1,2}=0,833$ Maka dapat dihitung produktivitas per jamnya dengan menggunakan rumus.

Produktivitas per jam $=\frac{\text { Kapasitas kerja per hari }}{\text { Durasi jam kerja normal }}$

$$
\begin{array}{ll}
\text { Durasi kerja normal } & =7 \text { jam } \\
\text { Durasi kerja lembur } & =2 \text { jam }+ \\
\text { Total jam kerja } & =9 \text { jam }
\end{array}
$$

\begin{tabular}{|c|c|c|c|c|c|}
\hline & & & & Durasi & \\
\hline No & Uraian Pekerjaan & $\begin{array}{c}\text { Tenaga } \\
\text { Kerja } \\
\text { Normal }\end{array}$ & $\begin{array}{c}\text { Durasi } \\
\text { Awal }\end{array}$ & $\begin{array}{c}\text { Tambah } \\
\text { Jam } \\
\text { Kerja } \\
\text { (Lembur) }\end{array}$ & $\begin{array}{c}\text { Biaya Tambah } \\
\text { Jam Kerja } \\
\text { (Lembur) }\end{array}$ \\
\hline
\end{tabular}

Tabel 5. Hasil Analisa Penambahan Jam Kerja (Lembur)

\begin{tabular}{|c|c|c|c|c|c|}
\hline No & Uraian Pekerjaan & $\begin{array}{c}\text { Tenaga } \\
\text { Kerja } \\
\text { Normal }\end{array}$ & $\begin{array}{c}\text { Durasi } \\
\text { Awal }\end{array}$ & $\begin{array}{c}\text { Durasi } \\
\text { Tambah } \\
\text { Jam } \\
\text { Kerja } \\
\text { (Lembur) }\end{array}$ & $\begin{array}{c}\text { Biaya Tambah } \\
\text { Jam Kerja } \\
\text { (Lembur) }\end{array}$ \\
\hline 7 & $\begin{array}{l}\text { Plat Deck Selasar } \\
\mathrm{t}=8 \mathrm{~cm}\end{array}$ & 1 & 6 & 5 & $460,057.80$ \\
\hline 8 & Balok Lantai $12 / 20$ & 1 & 6 & 5 & $525,121.39$ \\
\hline 9 & Kanopi 5/50 & 1 & 21 & 17 & $525,121.39$ \\
\hline 10 & Pas WF 250.125.6.9 & 4 & 21 & 17 & $416,115.61$ \\
\hline 11 & Plat Deck $\mathrm{t}=12 \mathrm{~cm}$ & 12 & 11 & 9 & $2,040,763.01$ \\
\hline 12 & Balok Lantai $12 / 20$ & 1 & 21 & 17 & $525,121.39$ \\
\hline 13 & Kanopi 5/50 & 1 & 21 & 17 & $525,121.39$ \\
\hline & Total & \multicolumn{4}{|c|}{$16,846,855.49$} \\
\hline
\end{tabular}

\begin{tabular}{clcccl}
\hline 1 & Lantai Kerja 5 cm & 13 & 31 & 25 & $658,647.40$ \\
\hline 2 & $\begin{array}{l}\text { Fondasi Plat Beton } \\
\text { Menerus 20/100 }\end{array}$ & 19 & 21 & 17 & $4,465,595.38$ \\
\hline 3 & Kolom Beton 35/35 & 7 & 21 & 17 & $1,506,416.18$ \\
\hline 4 & Balok 15/30 & 1 & 6 & 5 & $525,121.39$ \\
\hline 5 & Plat Deck t=12 cm & 14 & 6 & 5 & $2,355,156.07$ \\
\hline 6 & Plat Deck t=12 cm & 14 & 16 & 13 & $2,318,497.11$ \\
\hline
\end{tabular}

(Sumber: Hasil Analisis 2021)

Selanjutnya dari hasil perhitungan crashing dengan alternatif penambahan tenaga kerja dan jam kerja lembur di buat dalam bentuk grafik berikut.

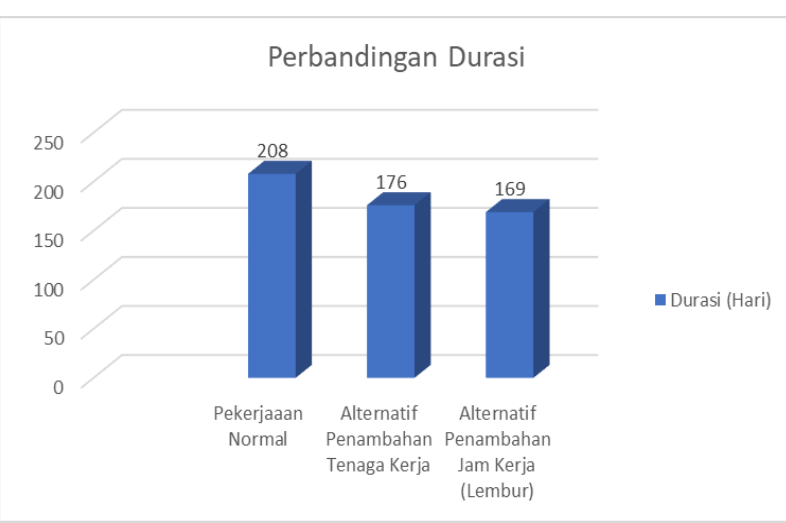

Gambar 4. Grafik Perbandingan Durasi Normal Dan Durasi Setelah Crashing

(Sumber: Hasil Analisis 2021)

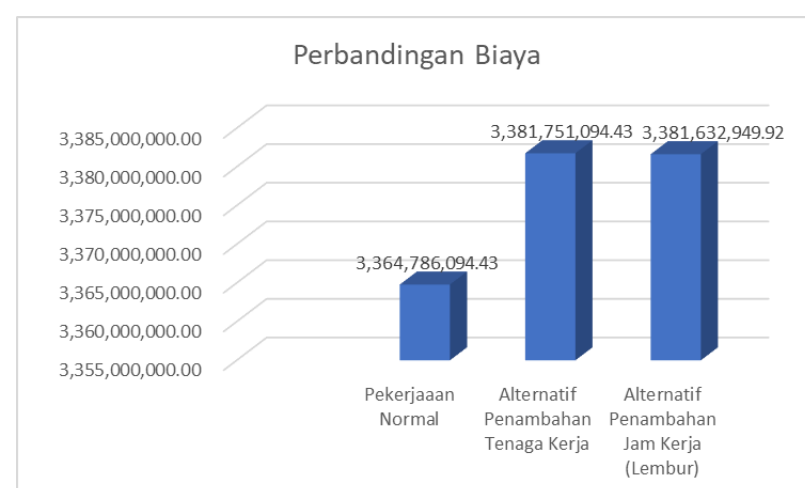

Gambar 5. Grafik Perbandingan Biaya Normal dan Biaya Setelah Crashing

(Sumber: Hasil Analisis 2021)

\section{KESIMPULAN}

1. Durasi awal pekerjaan konstruksi pembangunan proyek yaitu selama 160 hari kerja. Dari hasil analisa pada penelitian ini didapat durasi pelaksanaan pekerjaan bangunan proyek secara normal. Karena pada hal ini Proteksi/Desember 2021 Volume 3 No. 2 
tidak menekankan terhadap waktu tetapi lebih menekankan terhadap biaya.

2. Biaya upah tenaga kerja pada kondisi normal ialah sebesar Rp.3.364.786.094,43. Dari hasil analisa dengan alternatif penambahan tenaga kerja dengan biaya upah sebesar Rp.3.381.751.094,43. Sedangkan biaya upah dengan alternatif penambahan jam kerja (lembur) sebesar Rp.3.381.632.949,92.

Alternatif yang lebih ekonomis dalam penyelesaian proyek yaitu penambahan jam kerja (lembur) karena lebih hemat Rp.118.145,49 dari penambahan tenaga kerja. Apabila waktu dipercepat maka biaya juga lebih meningkat.

\section{SARAN}

Berdasarkan dari penelitian dan analis yang telah dilakukan, ada beberapa saran yang ingin peneliti sampaikan. Di antaranya sebagai berikut.

1. Metode yang digunakan dalam penelitian ini hanya menggunakan 2 alternatif yaitu penambahan tenaga kerja dan jam kerja (lembur). Maka akan lebih baik apabila ditambahkan dengan alternatif yang lainnya seperti penambahan material/peralatan dan lainnya.

2. Jika ingin melakukan penambahan sebaiknya dilakukan beberapa trial baik jumlah tenaganya maupun jumlah penambahan jam kerjanya agar didapatkan hasil yang optimal.

\section{REFERENSI}

A. Dwiretnani and A. Kurnia, "Optimalisasi Pelaksanaan Proyek Dengan Metode CPM (Critical Path Methode)," J. Talent. Sipil, vol. 1, no. 2, pp. 58-63, 2018.

A. Gunasti and A. Rofiqi, "Penerapan Metode Barchart , CPM , PERT dan Crashing Project dalam Penjadwalan Proyek Pembangunan Gedung $G$ Universitas Muhammadiyah Jember," J. Rekayasa Tek. Sipil Univ. Madura, vol. 4, no. 1, pp. 7-12, 2019.

A. H. A, "Perencanaan Dan Pengendalian Proyek Dengan Metode PERT-CPM: Studi Kasus FLY Over Ahmad Yani, Karawang," J. Winners, vol. 6, no. 2, pp. 155-174, 2005.

D. Fardila and N. R. Adawyah, "Optimasi Biaya dan Waktu Proyek Konstruksi dengan Lembur dan Penambahan Tenaga Kerja," INERSIA INformasi dan Ekspose Has. Ris. Tek. SIpil dan Arsit., vol. 17, no. 1, pp. 3546, 2021, doi: 10.21831/inersia.v17i1.39499.

D. Kartikasari, S. W. Sampurno, and P. E.
Agustyawan, "Evaluasi Biaya Pada Proyek Pembangunan Gedung Kecamatan Lamongan Menggunakan Metode Crashing," JURMATEKS, vol. 4, no. 1, pp. 191-202, 2021, doi: 10.1016/j.jksues.2020.10.001.A.

E. R. Anggraeni, W. Hartono, and Sugiyarto, "Analisis Percepatan Proyek Menggunakan Metode Crashing Dengan Penambahan Tenaga Kerja Dan Shift Kerja," e-Jurnal MATRIKS Tek. SIPIL, vol., no., pp. 1-49, 2017.

E. Safitri, S. Basriati, and L. Hanum, "Optimasi Penjadwalan Proyek menggunakan CPM dan PDM (Studi Kasus: Pembangunan Gedung Balai Nikah dan Manasik Haji KUA Kecamatan Kateman Kabupaten Indragiri Hilir)," J. Sains Mat. dan Stat., vol. 5, no. 2, pp. 17-25, 2019.

Erika Alfianti, "Optimalisasi Waktu Dan Biaya Pada Proyek Pembangunan Gedung Rawat Inap Puskesmas Wonoayu Sidoarjo Dengan Menggunakan Metode CPM (Critical Path Method)," Universitas Bhayangkara, 2019.

F. Y. Umbara and M. Abduh, "Analisis Keterlambatan Proyek Pasar Besar Ngawi Menggunakan Metode CPM (Critical Path Method)," pp. 7-14, 2020.

G. A. Putri Delvania Armanda, Muhtar, "Penerapan Metode CPM dan Crashing pada Proyek Gedung Training Center Universitas Jember Application of the CPM and Crashing Method in the Jember University Training Center Building Project, " J. Smart Teknol., vol. 2, no. 2, pp. 151-158, 2021.

Keputusan Menteri Tenaga Kerja Dan Transmigrasi Republik Indonesi, "Keputusan Menteri Tenaga Kerja Dan Transmigrasi Republik Indonesia Nomor KEP.102 /MEN/VI/2004 Tentang Waktu Kerja Lembur Dan Upah Kerja Lembur." pp. 1-5, 2004.

Latifah Siti, "Optimalisasi Manajemen Waktu Dan Biaya Terhadap Pembangunan Proyek (Studi Kasus Penyelesaian Pembangunan Puskesmas 1 Batur CV. SENDO HOKAGE)," J. Bus. Eng., vol. 1, no. 2, pp. 326-334, 2020.

M. Onibala, J. Tjakra, and P. A. K. Pratasis, "Optimasi Waktu Dan Biaya Dengan Metode Crash," J. Tekno, vol. 16, no. 69, pp. 7-10, 2018.

N. M. E. Wardani, S. Musdalifah, and D. Lusiyanti, "Optimalisasi Biaya Dan awaktu Pelaksanaan Pembangunan Perumahan Citraland Palu Menggunakan Metode Program Evaluation And Review Technique

Proteksi/Desember 2021 Volume 3 No. 2 
(PERT) - Critical Path Method (CPM)," J. Ilm. Mat. dan Terap., vol. 15, no. 2, pp. 197-208, 2018.

R. Hidayah, A. Ridwan, and Y. C. SP, "Analisis Perbandingan Manajemen Waktu Antara Perencanaan Dan Pelaksanaan," JURMATEKS, vol. 1, no. 2, pp. 281-290, 2018.

S. U. E. Suhendar, "Implementasi Metode Critical Path Method Pada Proyek Synthesis Residence Kemang," J. Optimasi Tek. Ind., vol. 03, no. 01, pp. 1-6, 2021.

Soeharto Iman, Manajemen Proyek (Dari Konseptual Sampai Operasional). 1999.
Undang-undang Republik Indonesia, "UndangUndang Republik Indonesia Nomor 13 Tahun 2003 Tentang Ketenagakerjaan." 2003.

Wulfram I. Ervianto, Manajemen Proyek Konstruksi, Revisi. Penerbit AN Dl Yogyakarta, 2005.

Y. Stefanus, I. Wijatmiko, and E. A. Suryo, "Analisis Percepatan Waktu Penyelesaian Proyek Menggunakan Metode Fast-Track And Crash Program," Media Tek. Sipil, vol. 15, no. 1, pp. 74-81, 2017. 